\title{
The Role of Japan-India Security Cooperation under the New Security Framework
}

\author{
Satoru Nagao*
}

\section{Abstract}

In recent times Japan and India are moving closer in the area of security. The rise of China, US strategic withdrawal from the Indian Ocean and Japan's increasing profile in the Asia-pacific region have contributed towards Japan's strong security partnership with India. In this regard this article analyses the three following questions: (1) What are the security activities that Japan has undertaken? (2) Why has Japan tried to share more security burden? (3) What can Japan-India cooperation do? Currently, Japan has enhanced its security cooperation with other US allies and friendly countries including Southeast Asian countries taking the US-China power balance into consideration. The changing security situation has pushed Japan to reconsider its security priorities. There is much scope for Japan and India to cooperate by using the linkage of East China Sea and Indo-China Border, share the burden of maritime security in the Indian Ocean region and collaborate to support countries around China in the South China Sea.

Keywords: Japan-India Security cooperation, US-China power balance, Indo-Pacific region

Visiting Fellow at Hudson Institute, Washington D.C. satorunagao1s@gmail.com 


\section{Introduction}

India and Japan are coming closer in recent times, especially in the security domain. Japan's stand on the recent Doklam incident between India and China, is a good example. In mid-2017, the armed forces of India and Bhutan faced China's incursion at Doklam in Bhutan. It was during the same time that Japan-IndiaUS had started their joint maritime exercise Malabar 2017 (on 6 July 2017 ) in the Indian waters. In this exercise, the largest warship of Japan, Izumo joined the exercises in the Indian Ocean. It is the first time that Japan has chosen to dispatch such a huge helicopter carrier to the Indian Ocean.

In a similar way, Indian Foreign Secretary Dr S Jaishankar said that "as a country that shares similar values and principles, Japan is comfortable partnering India as it assumes greater security responsibilities. We also see the enhanced synergy between India and Japan on connectivity and maritime security" in Singapore on 11 July (MEA, 2017a). In addition, Japanese ambassador to India Kenji Hiramatsu conveyed Japan's support to India and Bhutan by using the word "all parties involved should not resort to unilateral attempts to change the status quo by force" which is overtly critical of the Chinese attempt to "change the status quo" on 18 August 2017 (Roy, 2017). These examples show that the security ties between Japan and India are quite remarkable. In this regard, this article seeks to answer the following questions: Why has Japan sought security cooperation with India? What are the security activities that Japan has done? Why has Japan tried to share more security burden? What can Japan-India cooperation do for ensuring peace in the Indo-Pacific?

\section{Japan's security perception in the Indo-Pacific}

With the ever increasing challenge from China, Japan is enhancing its security cooperation with the US and its allies as well as friendly countries. Australia, UK, and France have long been the allies of the US. Japan cooperates actively with these countries by sharing information, holding joint exercises, and by jointly developing and producing defense equipment. For example, during Prime Minister Shinzo Abe's visit to Australia in January 2017, Japan and Australia 
signed a new Acquisition and Cross-Servicing Agreement, which will facilitate mutual logistical support including materials and ammunition for joint exercises, UN Peace Keeping Operations, etc. Japan is planning to export P-1 indigenous patrol planes to New Zealand, too ((MOFA, 2017). From 2014, Japan has been seeking a Joint New Air to Air Missile development project with UK (Thai Military, 2017). On October 2016, for the first time, Japan and UK held joint air combat exercises. Japan and France are also in negotiations to start joint arms development project.

Secondly, Japan is building the capacity of its defense forces in Southeast Asia. For instance, when a Malaysian airplane was lost in 2014, coastal countries could not contribute to the search of the plane because they had insufficient radar systems to detect it. To resolve that situation, they needed radar and sensor systems that they can deploy to be aware of events such as this and to address it by dispatching planes and ships. During Japanese Prime Minister Shinzo Abe's visit to Vietnam in January, Japan decided to donate six newly built patrol vessels (Panda, 2017). Japan has donated patrol vessels to Vietnam, Philippine, Indonesia and Malaysia. Japan is also planning to donate used P-3C patrol planes to Malaysia, Vietnam, and Sri Lanka. Export of radar to Thailand is also in the planning, too. Donating and exporting equipment are effective methods to promote long-term relations because the recipients need training and maintenance of suppliers.

There are two things that have driven Japan to help the Southeast Asian countries in this regard; Firstly, the changing security situation in the Asia-pacific region has pushed Japan to do so. A salient feature of the recent security situation is the changing contours of US-China military balance. For example, during 20002016, the US commissioned 14 new submarines. During the same period, China commissioned at least 43 submarines. Although it is expected that the US would prevail in case of a war, it is also true that US military influence has been declining gradually. Taking this into consideration, Japan is independently pushing for a strategic space in the Asia-Pacific security architecture.

It is very evident that from the second term of Barack Obama administration to the new Trump administration, the relative influence of US military power has continued to decline. Despite 
US failure to deter Russian actions in Crimea, Ukraine, and Syria, it is expected that President Donald Trump's government will seek cooperation with Russia. From the perspective of countries such as Ukraine and Moldova, which rely on the US, there is an increasing feeling that the US will abandon them in the near future. This sense of a change in the diplomatic equation has nudged Moldova towards negotiations with Russia.

As a result of this unstable US foreign policy in the recent times, allies and friendly countries of the US in the Indo-Pacific region also view the future with anxiety. The US has not dissuaded China from building artificial islands in the South China Sea. Allies and friendly countries of the US, including the Philippines and Vietnam, are concerned about the possibility that the US might strike some deal with China and abandon allies and friends' concern of China's increasing assertiveness. Philippines has already slightly changed their stance under the new president Rodrigo Duterte. Under his government, the Philippines has not taken a strong position in the case of development of artificial islands in the South China Sea. Although US President Trump promises to increase the number of warships and fighter jets to "make America great again," the influence of the US as a security provider has been declining. US allies and friendly countries now require a new security framework to adjust to the situation.

Since the Obama administration, a new security framework has emerged. For a long time, bilateral alliances led by the US, such as those of Japan-US, US-Australia, US-Philippines, and US-South Korea have maintained order in the Indo-Pacific as an "old" security framework resembling a "Hub and Spoke system." In the system, a deep defense relation is lacking among the allies. For example, both Japan and Australia are US allies, but they share no close security relations. Under this system, the allies and friendly countries of the US are heavily dependent on US military power. US influence is declining. Therefore, the reliability of the entire security framework is declining.

Consequently, a new security framework has emerged. This framework is a security network of numerous bilateral, trilateral, quadrilateral, other multilateral cooperative relationships among US allies and friendly countries. This cooperation includes not only 
US-led cooperation such as Japan-US-Australia, Japan-India-US, and Japan-India-US-Australia, but also Japan-India-Australia and India-Australia-Indonesia, which do not include the US (Figure 1).

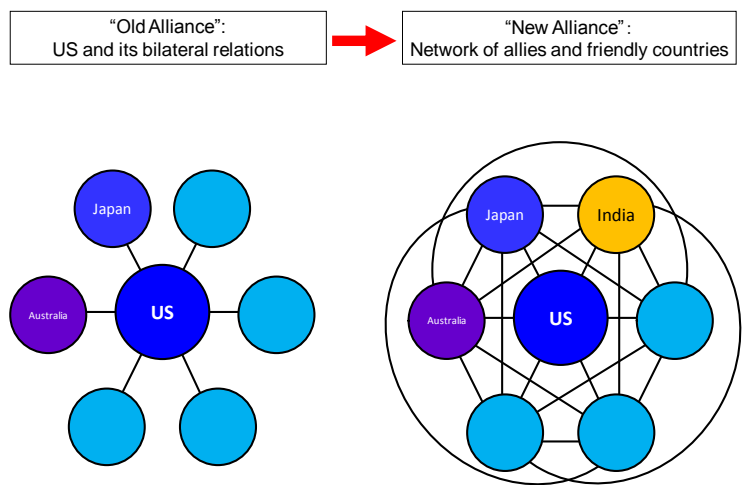

Fig 1 "Old" and "New" security frameworks

Source: Satoru Nagao, "The Japan-India-Australia "Alliance” as Key Agreement in the IndoPacific", ISPSW Publication September 2015, Issue No. 375, (Berlin, The Institute for Strategic, Political, Security and Economic Consultancy (ISPSW))http://www.isn.ethz.ch/Digital-Library/ Publications/ Detail/?en\&id=193713 (accessed September 23 2015)

This new security framework presents several strong points of marked benefit. First, because this system is not heavily dependent on US influence, the adverse impact of the declining US influence will be minimal. Secondly, because this system includes India and Southeast Asian countries that have rising influence, the security framework can maintain sufficient power for a long time. Furthermore, a multilateral system demands that countries adopt a rule-based approach. In fact, it would be in the best interest of every country involved that China and Russia also are allowed to join, only if they agree to follow the set of rules accepted by everyone. Therefore, the new security framework offers the important possibility of reducing tensions in this region.

\section{India-Japan Strategic Cooperation}

India-Japan Strategic cooperation is one of the main catalysts of enduring peace and stability in Asia. Both countries consider China as a long term threat. In this regard, there are three areas especially where Japan-India security cooperation can help maintain the military balance with China and support new security framework. 
In Indo-China border area, the military balance is changing because Chinese military infrastructural modernization is very fast. During the 2013 skirmish between the Indian and PLA Army, Chinese armed forces got ready within 48 hours for battle in the border area whereas India needed one week for preparation as there are not enough roads on the Indian side (Tiwary, 2013). If a similar situation arises, India could be in a dangerous situation of facing more than three times its size Chinese forces in the border area (Pandit, 2012).

Along with such rapid military modernization, the area of Chinese military activities too has been widening. As a background to the Doklam incident in 2017, India recorded more than 300 incursions per year, since 2011. In addition, China is deploying troops in Pakistan administered Kashmir as well as a part of "China-Pakistan Economic Corridor". Thus, because of geographical location where they are just located at opposite sides of China, Japan-India cooperation can rectify their respective numerical inferiority. For example, if India cooperates with Japan, India will not need to deal with all the Chinese fighters at once because China is likely to keep some of their fighters in their east side against Japan and vice versa (Singh, 2013).

Therefore, under the Japan-India strategic cooperation, by using know-how of high-end military infrastructural development, Japan is willing to support India's efforts to modernize India's defence in the Indo-China border area. Since 2014, Japan has planned to invest in India's strategic road project in the Northeast region of India. By using this road, the Indian army can deploy more forces and supply to the border area. This road building project is just a beginning. Because the Japanese government will ease regulations that restrict Japan's Official Development Assistance to support security related infrastructural projects, further substantial support from Japan's side may be expected in India's strategic projects like construction of roads, tunnels, airports and helipads of strategic importance. In addition, Japan may also export radar systems to India to strengthen air defence and air control capabilities in the Indo-China border area.

India's rise helps lower the heavy burden of Japan and US in the Indian Ocean 
Secondly, in the Indian Ocean, China has recently started to increase their military activities in the littoral area. China is concerned about their energy dependence on Sea Line of communications (SLOCs) from Middle East to China through the Strait of Malacca. Although they have tried to make an alternative route via Middle East-Pakistan-China and/or Middle EastMyanmar-China etc. connecting the Indian Ocean through a land route circumventing the Malacca, as a part of "One Belt One Road" initiative. China feels that if India or the US choke the SLOCs it would severely affect Chinese economic growth. In order to avoid such a threat, China has been expanding its military activities in the Indian Ocean since the middle of 2000s. China has continuously deployed its naval ships in the Indian Ocean in the guise of antipiracy operations. At least seven deployments were recorded with Chinese submarines patrolling in the Indian Ocean since 2013 (The Indian Express, 2017). In addition, China also exports submarines to countries around India. Bangladesh received two submarines from China in 2016 and Pakistan decided to import eight Chinese submarines for their navy. It must also be noted that Pakistan, may also be willing to purchase nuclear submarines. Because Pakistan does not have the technology, there is again reasonable possibility that China will support the building of such "indigenous" nuclear submarines to counter India.

The activities of these submarines indicate that the area of influence of China in the Indian Ocean is going to expand. The Indian Navy will need to have enough ships to keep a regular watch over the location and purpose of other countries' submarines, because these "Chinese" submarines can potentially attack India's nuclear ballistic missile submarines (INS Arihant) and SLOCs. This means that these submarines will, to a great deal, regulate India's naval activities.

China's strategic weakness is, however, that it does not have a naval port in the region. Therefore, China is setting up their base in Djibouti. In addition, under the "String of Pearl Strategy", China is investing to develop many ports such as Gwadar in Pakistan, Hambantota in Sri Lanka, Chittagong in Bangladesh and Kyaukpyu in Myanmar in the Indian Ocean. If the Chinese navy uses civil-purpose ports as naval supply bases, China could 
successfully tackle their weakness of not having a naval port in the region. Currently, China is planning to deploy two marine brigades to defend its base in Djibouti and Gwadar (The Indian Express, 2017a).

\section{India set to play key role in the Indian Ocean}

The question that is of importance to any maritime strategist is that, why has China's assertiveness heightened in the Indian Ocean lately? The changing US-China military balance could have affected the situation. The US influence in the India Ocean region increased in the 1970s. The US dispatched aircraft carrier battle groups several times in order to respond to conflicts within the region, such as the third Indo-Pakistan War of 1972, the Gulf War, Operation Enduring Freedom after 9/11, and the Iraq War. The US used the island of Diego Garcia as a hub to deploy military power. However, because US naval power has been declining, China has been increasing naval activities in the Indian Ocean like in the East China Sea and South China Sea. Thus, we need to find an alternative country to fill a potential power vacuum in this region.

There is a high possibility that, in the near future, India will be the most influential sea power to fill the power vacuum in the Indian Ocean Region. There are six reasons which Alfred Thayer Mahan (1890) who analysed why Britain had been a sea power, pointed out. He listed six core factors i.e. 1) Geographical Position, 2) Physical Conformation (especially, the length of coast lines), 3) Extent of Territory (especially the balance between the extent of coastal line and military defence resources), 4) Size of Population (for working at sea), 5) Character of the People, and 6) Character of the Government (Hobson, 2002).

Taking these factors into account, first of all, India has advantageous "Geographical Position" because the Indian subcontinent is separated from the Eurasian continent by high mountains. This advantage has historically proven to be significant. There were only three empires which dominated most of the subcontinent in Indian history: the Mauryan Empire, the Mughal Empire and the British Raj. The territories of these three empires were very similar and all their territories are based on the mountain 
range (Figure 3). Thus, the Indian sub-continent is a kind of island. And India can concentrate on its naval forces only if it possesses the necessary will.

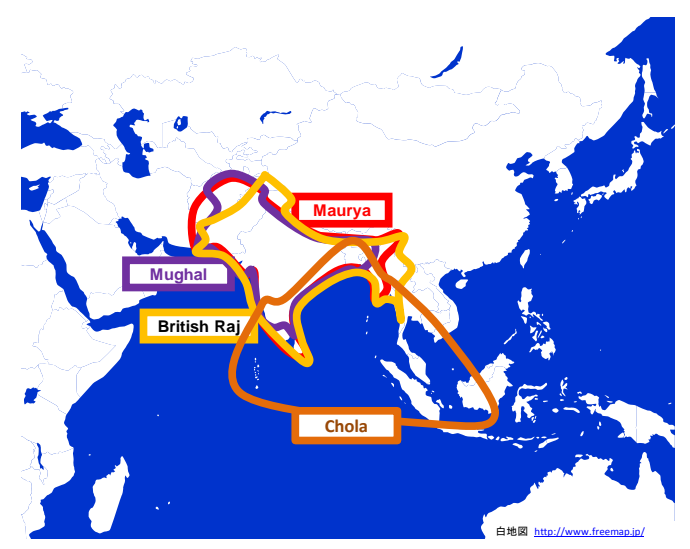

Fig 3 Influential area of empires in the sub-continent

Source: Satoru Nagao, “The emerging India is not a threat. Why? An assessment from Japan" Asia Pacific Journal of Social Science, Vol. III, Jul.-Dec. 2012, pp.99-109.

In addition, the history of Cholas indicates another geographical advantage for India. Representatives of the Chola Empire, which was located in Southern India, made an expedition to Southeast Asia in the 11th century. The sphere of its influence had expanded along the entire coastal area off the Bay of Bengal. This historical fact is another prominent example of India's geographical advantage. Since India is located at the northern centre of the Indian Ocean, it is not only able to access Southeast Asia, but also all sides of the Indian Ocean, including the Middle East and East Africa. In fact, India has "Physical Conformation" because it has 7517 (only mainland 6100) km of coastline. And the Indian Navy is the only strong power as a coastal country of the Indian Ocean Region means that India has enough "Extent of Territory". Presently, India is in the process of acquiring more than 100 warships. And by 2030, India is planning to increase the warships from 139 to 212 (Subramanian, 2016). There is a possibility that India will possess three aircraft carrier battle groups and nine nuclear submarines by 2030 (The Times of India, 2013). 
India has the fifth or sixth largest number of seafarers, about 55,000 sailors employed around the world. Thus, India also satisfies the condition of "Number of Population" working at sea. Based on the history of the Chola Empire, there is also a possibility that the "Character of the People" in India could be sea-power oriented. And finally, taking these two characteristics and the "Character of Government" into account, the Indian government is interested in expanding its sea power. The 2012 "Nonalignment 2.0: A Foreign and Strategic Policy for India in the Twenty First Century" report, based on the discussions of many former National Security Advisors of India states that "presently, Indian military power has a continental orientation. Emerging as a maritime power should thus be India's strategic objective" (Khilnani et al, 2013). And India's defence budget has increased the share of its navy from $12.7 \%$ in 1990 to $15.8 \%$ in 2015 (MOD, 2016).

Thus, according to Mahan's theory, India has sufficient potential to become a sea power and thereby an influential country in the Indian Ocean Region. If India has the required will and develops sufficient capabilities, the cooperation with India could contribute a lot for Japan. This is because Japan and its ally US will be able to release themselves from the heavy burden to safeguard security in the Indian Ocean and can deploy more military force in the East China Sea and West China Sea to maintain the military balance in Asia.

\section{Japan-India collaborate to support coastal countries in the Indian Ocean}

When we think about developing infrastructure in countries around India, Japan-India cooperation is useful there too. In the countries around India, China has invested heavily to build infrastructure and expanded their influence. If India does not possess enough budget and technology, China will increase their influence in the Indian Ocean Region and harm the 'great power image' of India. For example, Sri Lanka has an important location safeguarding sea lines of communications in the Indian Ocean. Owing to this, China has been very active in the immediate area. In fact, China is building ports in Colombo and Hambantota. Along with economic support, Chinese submarines have visited Sri Lanka. If China supports Sri Lankan development, then little 
motivation exists for Sri Lanka to refuse economic support from China.

Thus, Japan-India cooperation is a useful method to rectify India's individual numerical inferiority. Japan and India can cooperate to develop Triconmalee Port to neutralize China's influence. If India's knowledge in South Asia and Japan's budget and technology could be coupled, India's influence would strengthen. Currently, Japan and India are planning to develop Chabahar Port in Iran. And "Asia-Africa Development Corridor" vision, based on India's goodwill and Japan's financial resources was launched in 2017 (Chaudhury, 2017).

\section{Japan and India can collaborate to support countries around South China Sea}

India's "act east" policy is now getting strategic support from the Southeast Asian countries in recent times. In the South China Sea, China's military power is far bigger than other countries. The countries around South China Sea need to amalgamate their leadership as one integrated power and beef up their military power with a trustworthy partner to provide coastal countries with military support. In this case, Japan-India strategic cooperation will be useful. "With increasing Chinese assertion in the South China Sea since 2001, many countries like Vietnam, Philippines and Singapore want India's increased presence in the Southeast Asia (Jha, 2013)." And by now, India has already started to support armed forces in Southeast Asia as a part of "Look East Policy" and its updated version "Act East policy". India has trained the crew of aircraft carrier of Thailand, pilots and the land crew of fighter airplanes in Malaysia. Further, India has agreed to train the pilots and provide maintenance to the fighter airplanes in the Indonesian Air Force. Singapore is using India's land and air base for their training. Especially, India-Vietnam security cooperation has developed. India is training the crew of submarine and fighter pilots of Vietnam, plans to export BrahMos cruise missile and Akash surface to air missile to Vietnam and plans to donate four patrol vessels to Vietnam.

Japan has never supported armed forces in Southeast Asia, but has always supported in putting in place anti-piracy system, Tsunami warning system, cyber defence system and building infrastructure like air and sea ports etc. These systems are indirectly related to 
maritime security in South China Sea. In addition, under the current Prime Minister Shinzo Abe, Japan has also started arms donation to these countries. For example, Japan will donate patrol ships to Vietnam and the Philippines.

Thus, if Japan and India collaborate with each other, both countries can support the regional countries around South China Sea more effectively. For example, if Japan built the airport in Vietnam and the Indian Air Force trained Vietnam's fighter pilots, Vietnam can get both an airport and fighter pilots. Furthermore, if accepted by Vietnam, both Japan and India can share the airbase for refueling and thus support Vietnam by showing their presence in this region. Hence, under the Japan-India-Vietnam cooperation, we can create a win-win-win situation.

To achieve this goal, what kind of systems ought to be established? In January 2014, when PM Abe visited Delhi, the two prime ministers "welcomed the launch of a bilateral dialogue on ASEAN affairs." It will be useful if such dialogue will promote a more practical trilateral strategic dialogue. For example, Japan-IndiaVietnam, Japan-India-Philippines, Japan-India-Singapore, JapanIndia-Indonesia, Japan-India-Malaysia etc. As a result of such dialogues, both Japan and India can share information, better identify the needs of the Southeast Asian countries and decide how to cooperate or support these countries.

\section{Conclusion: Japan-India-Sri Lanka cooperation will be vitally important}

To summarize the salient points of the article, it is important for Japan to enhance security cooperation with other US allies and friendly countries including Southeast Asian countries. The reason is related to US-China power balance. From the second term of the Obama administration and into the new Trump administration, US influence in the Asia-Pacific region has been on the decline. The possibility exists that the Trump administration needs more time to re-establish a security policy and show its influence effectively. During this time, Japan will play a role of vital importance. Japan should allay the concerns of Asian countries supported by the US. Since the Obama administration, a new security framework has 
emerged that values Japan-India cooperation and believes that it has an important role. To maintain military balance and support the new security framework, Japan and India can cooperate by using the linkage of East China Sea and Indo-China Border, share the burden in the Indian Ocean and collaborate to support countries around China in the South China Sea. India's behaviour is also likely to remain that of a responsible power. Collectively speaking then, these seem to be the reason why Japan is seeking more cooperation with India lately. The time has come to proactively further this cooperation to ensure prosperous stability in the whole of Indo-Pacific.

\section{Reference}

Chaudhury, D. (2017, May 26). India, Japan-come-up-with-AAGC-tocounter-China's-OBOR. The Economic Times. Retrieved from https:// economictimes.indiatimes.com/news/economy/policy/india-japancome-up-with-aagc-to-counter-chinasobor/articleshow/58846673.cms

Hobson, R. (2002). Imperialism at Sea: Naval Strategic Though, the Idelology of Sea Power, and the Tirpiz Plan, 1875-1914. Boston: Brill Academic.

India, Government of India, Ministry of Defence. (2016). Annual Report 2015-2016. New Delhi: Ministry of Defence. Retrieved from https://mod.gov.in/sites/default/files/Annual2016.pdf

Jha, P. K. (2013). India and China in Southeast Asia: Competition or Cooperation?. New Delhi: Manas Publishcations

Khilnani, S., Kumar, R., Mehta, P. B., Menon, P., Nilekani, N., Raghavan, S., Saran, S. \& Baradarajan, S. (2012). Nonalignment 2.0: A Foreign and Srategic Policy for India in the Twenty-first Century (P.38). Penguin.

Ministry of Foreign Affairs (MOFA). (2017b). Prime Minister Abe's Visit to Australia. Government of Japan, January 15. Retrieved from http://www.mofa.go.jp/a_o/ocn/au/page3e_000640.html

Ministry of Foreign Affairs Government of India (MEA). (2017a). "Speech by Dr. S. Jaishankar, Foreign Secretary to mark 25 years of IndiaSingapore Partnership at Shangri La Hotel," Singapore. July 11. Retrieved from http://www.mea.gov.in/SpeechesStatements.htm?dtl/28609/Speech_by_Dr_S_Jaishankar_Foreign_Secr etary_to_mark_25_years_of_IndiaSingapore_Partnership_at_Shangri_ La_Hotel_Singapore_July_11_2017

Panda, A. (2017, January 17). Japan Pledges 6 New Patrol Boats for Vietnam Coast Guard. The Diplomat. Retrieved from http:// 
thediplomat.com/2017/01/japan-pledges-6-new-patrol-boats-forvietnam-coast-guard/

Pandit, R. (2012, August 16). India boring border tunnels to take on China, Pakistan. The Times of India. Retrieved from http:// articles.timesofindia.indiatimes.com/2012-08-

16/india/33232484_1_tunnels-rangpo-sikkim

Roy, S. (2017, August 19). India-China standoff at Doklam: Japan throws weight behind India and Bhutan, says no side should try to change status quo by force. The India Express. Retrieved from http://indianexpress.com/article/india/standoff-over-doklamtokyo-throws-weight-behind-delhi-4801881/

Singh, R. (2013, December 12). India far behind China's Combat Power. Hindustan Times. Retrieved from http:/ /www.hindustantimes.com/ india-news/india-far-behind-china-s-combat-power/article11161711.aspx

Subramanian, K.S. (2016, December 12). Bridge the Gap Between Plan and Execution What Ails Warship Building in India. Indian Military Review. 10-12.

Tiwary, D. (2013, August 23). 'Chinese clearing border land to grab land'. The Times of India. Retrieved from http:// articles.timesofindia.indiatimes.com/2013-08-26/ india/ 41453967 _1_chinese-troops-incursion-sino-indian-border

Thai Military. (2017, January 16). Japan-UK collaborate research on development of next-generation Air-to-Air Missile technology "JNAAM". Retrieved from https:// thaimilitaryandasianregion.wordpress.com/ 2017/01/20/japan-ukcollaborate-research-on-development-of-next-generation-air-to-airmissile-technology-jnaam/

The Indian Express (2017a, March 13) China may station Marines in Gwadar, say PLA insiders. The Indian Express.

The New Indian Express. (2017, March 30). Six cases of Chinese submarine deployment in four years: Navy Chief Sunil Lamba. The New Indian Express. Retrieved from http:// www.newindianexpress.com/ states/tamil-nadu/2017/mar/30/six-cases-of-chinese-submarinedeployment-in-indian-ocean-in-four-years-navy-chief-sunil-lanba1587558.html.

The Times of India. (2013, November 13). Indian Navy to have 200 warships in next 10 years. The Times of India. Retrieved from http:// articles.timesofindia.indiatimes.com/2013-11-13/india/

44028232_1_ins-vikramaditya-navy-day-ins-khukri 